\title{
SOME STUDIES ON CONTROLLING THE ACTION OF LIPASE AND LINAMARASE DURING RUBBER SEED KERNEL PROCESSING
}

\author{
G. VITHARANAGE MALLIKA, E.R. JANSZ, NIRMALA M. PIERIS \\ Ceylon Institute of Scientific \& Industrial Research, 363, Bauddhaloka Mawatha, \\ Colombo 7, Sri Lanka.
}

AND

A.M. ABEYSEKARA

Department of Chemistry, University of Sri Jayewardenepura, Nugegoda, Sri Lanka.

(Date of receipt : 20 March 1991)
(Date of acceptance : 10 September 1991)

\begin{abstract}
Rubber seed kernel contains a lipase whose action results in free fatty acio formation and linamarase (EC 3.2.1.21) liberating cyanide from cyanogenic glucosides. Both enzymes require moisture to act, the former a detrimental action and the latter a beneficial one. The critical path of rubber seed kernel processing appears to be collection of seeds fresh (preventing germination induced lipases from acting) and drying to $10-12 \%$ moisture to prevent basal endogenous lipase activity and thus produce an oil low in free fatty acid. Linamarase not only acts during drying to liberate $>70 \%$ cyanide but also survives the drying and oil expelling stages of processing. The surviving endogenous enzyme activity can be utilized to detoxify rubber seed meal upon re-moistening.
\end{abstract}

\section{Introduction}

Industrial utilization of rubber (Hevea brasiliensis) is constrained by four main problems. Namely, the presence of high levels of free fatty acids, aflatoxins, cyanogenic glucosides and cyanide and polyisoprenoids. ${ }^{6}$ Of these, control of aflatoxins is a post-harvest problem, while the polyisoprenoids can be removed from the oil by a relatively simple process. ${ }^{7}$ As such, this study concentrates on limiting free fatty acids (FFA) formation which results in rubber seed oil of reduced value and the presence of cyanogenic glucosides and cyanide (together termed total cyanide), which remains in the meal after oil expulsion. The former detracts not only from the use of rubber seed oil as an edible oil, but also limits its industrial applications, while total cyanide limits use of rubber seed meal in animal feed.

Control of these problems largely lie in the control of enzymatic activity, i.e. preventing lipase activity while promoting linamarase activity during processing. This study reveals a simple strategy to achieve these ends. 


\section{Experimental}

\subsection{Samples}

Rubber seeds were collected from the field while fresh i.e preferably one day from seed-fall. Samples of seed were decorticated and immediately dried at $80^{\circ} \mathrm{C}$ in a forced draft oven (ot as othorwise specified in the text) to approximately $10 \%$ moisture.

\subsection{Determination of free faty acid ( $\mathrm{FH}$ (T)}

Dried powdered seeds were extracted in a Soxhlet apparatus for 4 h with petroleum ether $\left(60-80^{\circ} \mathrm{C}\right)$ and the solvent recovered to give the oil. The dricd oil $(2-3 \mathrm{~g})$ was used to determine the concentration of PFA ${ }^{1}$ which has been calculated as oleic acid.

\subsection{Development of $\mathrm{F}$ an Germination}

Fresh rubber seeds (which incidentally has no dormancy period) were germinated in a bed. The bed was covered with fine soil to a depth of $4 \mathrm{~cm}$ and the seeds pressed flat side downward until the upper surface of the seed was level with the soil. The bed was kept moist by watering at least once a day while preventing water-logging." FFA of the seeds were measured at varying time intervals using the method of Section 2.2.

\subsection{Test for Endogenous Limase}

Rubber seed kernel (50g) was crushed and homogenised with $100 \mathrm{~cm}^{3}$ watcr containing sorbic acid $\left(1 \mathrm{~g} \mathrm{dm}^{-3}\right)$ and sodium benzoate $\left(1 \mathrm{~g} \mathrm{dm}^{-3}\right)$ and adjusted to $\mathrm{pH}$ 8.5 with $0.1 \mathrm{M}$ phosphate buffer. Portions of the homogenate $(10 \mathrm{~g})$ were removed at intervals $(0,2,7,24$ and $48 \mathrm{~b})$ and subjected to freeze drying. Free fatty acid content was measured as in Section 2.2 .

\subsection{Total Cyanide Analysis}

Total cyanide was analysed after $24 \mathrm{~h}$. autolysis using a sample size of $6-8 \mathrm{~g} .{ }^{3}$ Exogenous linamarase was also used (when indicated in text) by the method of Pieris et al. ${ }^{4}$

\section{Results and Discussion}

\subsection{Free Fatty Acid Formation}

Past studies ${ }^{6,7}$ had shown that: (i) free fatty acid (FFA) reached unacceptably high levels ( $>10 \%$ on ageing), (ii) such levels were attained faster in the field than on storage in the laboratory, (iii) seeds should be dried to $5 \%$ moisture to prevent (FFA) build up, (iv) fungal growth was the probable causative agent for FFA formation (i.e. exogenous fungal lipases) and (v) endogenous lipases were not evident.

Preliminary studies with one day old seeds showed that, even at 11-12\% moisture, limited periods of storage does not lead to FFA build up (Table 1). 
Table 1:Effect of Moisture Content and Storage on Tree Faty Acids

\begin{tabular}{|c|c|c|c|}
\hline & $\begin{array}{l}\text { ge time } \\
\text { ays) }\end{array}$ & $\begin{array}{c}\text { Moisture } \\
(\%)\end{array}$ & $\begin{array}{l}\text { FFA } \\
(\%)\end{array}$ \\
\hline \multirow[t]{5}{*}{ A } & 0 & $11-12$ & 0.4 \\
\hline & 1 & & 0.3 \\
\hline & 2 & & 0.4 \\
\hline & 3 & & 0.4 \\
\hline & 4 & & 0.4 \\
\hline \multirow[t]{5}{*}{$\mathrm{B}$} & 0 & $7-8$ & 0.4 \\
\hline & 1 & & 0.3 \\
\hline & 2 & & 0.4 \\
\hline & 3 & & 0.4 \\
\hline & 4 & & 0.3 \\
\hline \multirow[t]{5}{*}{$\mathrm{C}$} & 0 & $0.5-0.6$ & 0.3 \\
\hline & 1 & & 0.3 \\
\hline & 2 & & 0.2 \\
\hline & 3 & & 0.3 \\
\hline & 4 & & not determined \\
\hline
\end{tabular}

Moisture levels of $\mathrm{A}, \mathrm{B}$ and $\mathrm{C}$ were obtained by heating kernels in forced draft oven at $80^{\circ} \mathrm{C}$ for $3.5,7$ and $24 \mathrm{~h}$. respectively.

Free fatty acids are expressed as a percentage of oil.

Further studies led to the following data:

(i) At higher moisture levels (15-24\%), FFA builds up to the order of $10 \%$ in 12 days. Such a build up. was not observed in seeds at $10-12 \%$ moisture, and (ii) if older seeds were used i.e. higher initial FFA $(\sim 4 \%)$ levels of $25 \%$ FFA were developed within 12 days.

An attempt was made to understand the reason for FFA build up.

\subsection{Germination Experiments}

Table 2 gives data collected from gemination experiments. It clearly shows that in as short a time as 12 days FFA can rise to as high as $75 \%$. Measurement of saponification value of oil showed that glycerides plus FFA adds up to approximately $100 \%$ showing that what is being observed is true lipase activity. This lipase activity thus appears to be germination induced. 
Table 2: Development of Free Fatty Acid Content During Germination of Rubber Seeds

\begin{tabular}{lr}
\hline Time (days) & $\begin{array}{c}\text { FFA } \\
(\%)\end{array}$ \\
\hline 0 & 1.1 \\
7 & 9.2 \\
12 (rooted) & 75.0 \\
16 (rooted) & 64.0 \\
16 (shoot) & 64.0 \\
20 (shoot) & 52.0 \\
20 (shoot) & 66.0 \\
16 (ungerminated) & 1.8 \\
\hline
\end{tabular}

Fresh rubber seeds were incubated in moistened soil.

\subsection{Test for Basall Lipase Activity}

Tables 3 and 4 show that FFA builds up on incubation of homogenized extract, and that basal endogenous lipase activity is present.

The general conclusion is that provided seeds are fresh and moisture is reduced $1012 \%$, lipase activity can be controlled.

Table 3: Erfect of Endogenous Lipases in Rubber Seed Kernel on Development of Free Fatty Acid

\begin{tabular}{cc}
$\begin{array}{c}\text { Time of incubation } \\
(\mathrm{h})\end{array}$ & $\begin{array}{c}\text { FFA } \\
(\%)\end{array}$ \\
\hline Fresh seeds & \\
\hline 0 & 2.3 \\
2 & 3.3 \\
7 & 3.6 \\
24 & 8.8 \\
48 & 8.0 \\
Old seeds & \\
0 & 9.1 \\
7 & 9.2 \\
24 & 16.2 \\
48 & 19.0
\end{tabular}

Rubber seeds were homogenized (in $0.1 \mathrm{M}$ phosphate buffer $\mathrm{pH} 8.5$ ) and incubared with sorbic acid $\left(1 \mathrm{~g} \mathrm{dm}^{-3}\right)$ and sodium metabisulphite $\left(1 \mathrm{~g} \mathrm{dm}^{-3}\right)$ under ambient conditions. FFA was measured at the time intervals indicated. 
Table 4: Effect of Endogenous Lipases in Immature Rubber Seed Kermel on Development of Free Fatty Acids

\begin{tabular}{cc}
\hline $\begin{array}{c}\text { Time of incubation } \\
(\mathrm{h})\end{array}$ & $\begin{array}{c}\text { FFA } \\
(\%)\end{array}$ \\
\hline 0 & 0.7 \\
2 & 3.0 \\
7 & 11.4 \\
24 & 14.0 \\
48 & 18.6 \\
\hline
\end{tabular}

Rubber seeds taken directly from fruit were homogenized and incubated with sorbic acio $\left(1 \mathrm{~g} \mathrm{dm}^{-3}\right)$ and sodium metabisulphite $\left(1 \mathrm{~g} \mathrm{dm}^{-3}\right)$ under ambient conditions. FFA was measured at the time intervals indicated.

\subsection{Total Cyanide of Rubber Seed Kernel}

Total cyanide content of rubber seed kernel can be as high as $7500 \mathrm{mgkg} .{ }^{-1}$ On ageing (or storage) the cyanogenic glucosides are hydrolysed and is quickly lost as $\mathrm{HCN}$ (Table 5). Although utilizing the highly cyanophoric natural enzymes to release $\mathrm{HCN}$ would seem a good solution, storage or ageing will also lead to the build up of FFA. Therefore it appeared logical to initially concentrate on preventing FFA formation and pay attention to bound cyanide (the cyanogenic glucosides) at a later stage.

Table 5: Loss of Total Cyanide on Storage of Fresh Rubber Seeds

\begin{tabular}{lcc}
\hline Time & $\begin{array}{c}\text { Total Cyanide } \\
\left(\mathrm{mg} \mathrm{kg}^{-1} \text { on dry basis }\right)\end{array}$ & $\begin{array}{c}\text { Loss of Total Cyanide } \\
(\%)\end{array}$ \\
\hline 0 & 7117 & 0 \\
1 & 4849 & 32 \\
2 & 4199 & 41 \\
4 & 1175 & 85 \\
7 & 268 & 96 \\
9 & 239 & 97 \\
\hline
\end{tabular}

Storage was carried out by spreading evenly on paper at ambient tempcrature.

Initial moisture content of kernels, $49.5 \%$.

\subsection{Effect of Drying on Total Cyanide}

The effect of drying rubber seed on total cyanide content is illustrated in Figure 1 where total cyanide levels fall to $\sim 20 \%$ the initial value on drying in a forced draft oven with an air flow rate $0.03 \mathrm{~m} 3 \mathrm{~s}-1$ at $800 \mathrm{C}$. The figure indicates that cyanide release slows when moisture content falls below $20 \%$. In other words enzyme activity ceases due to loss of moisture. Remoistening of dried rubber seeds results in resumption of enzyme activity (Table 6) and release of further cyanide, thus showing that at least part of the linamarase is still active. 


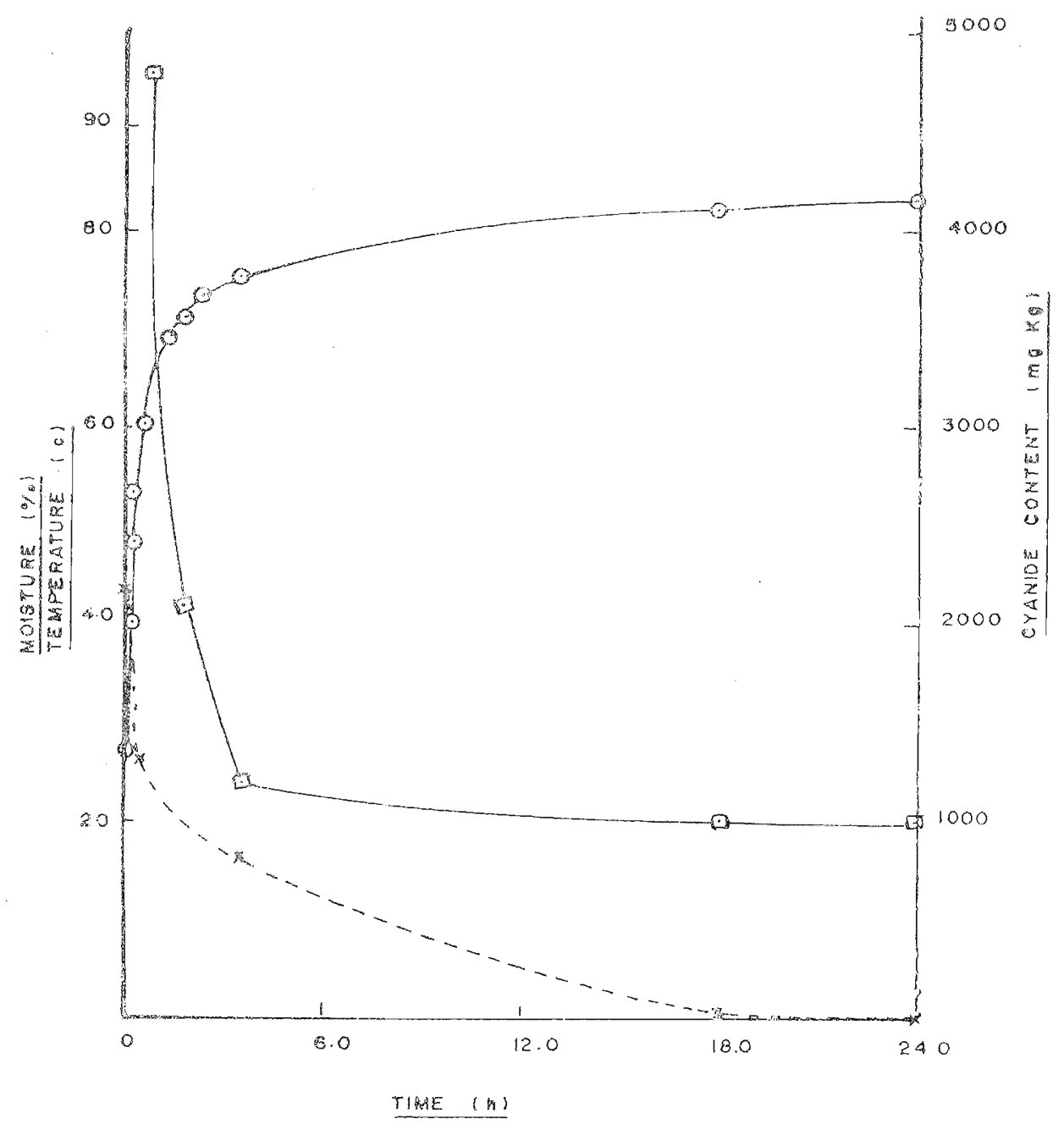

Figure 1: Cofect of arying on moisture coment, total cyanide content and kernel temperature.
$x-1-x$ Moisture content
$\square-\square$ Cyanide content
$0+0$ Temperature 
Table 6: Activity of Linamarase after Drying of Whole Rubber Seeds

\begin{tabular}{ccc}
\hline $\begin{array}{l}\text { Incubation } \\
\text { Period (b) }\end{array}$ & \multicolumn{2}{c}{ Total Cyanide $\left(\mathrm{mg} \mathrm{kg}^{-1}\right.$, on dry basis $)$} \\
\cline { 2 - 3 } & A & B \\
\hline 0 & Not determined & $27-53$ \\
0.5 & $292-230$ & $204-214$ \\
1 & $215-279$ & $207-223$ \\
2 & $122-164$ & $230-243$ \\
4 & $302-304$ & $195-336$ \\
6 & $120-208$ & $187-281$ \\
17 & $150-195$ & $206-216$ \\
24 & $171-432$ & $213-218$ \\
48 & $302-304$ & $252-253$ \\
\hline
\end{tabular}

A. Seeds were dried at $500 \mathrm{C}$ for $3-4$ days

B - Seeds were dried at $750 \mathrm{C}$ for $8 \mathrm{~h}$.

Moisture content of dried seeds $2.5 \%$

Dried kernels homogenised in water $(200 \mathrm{~cm} 3)$ and incubated for autolysis for the periods indicated. Cyanide isolated indicates action of linamarase.

Number of determinations were two.

\section{3.t Detoxification of Rutober Seed Meal}

Having expelled rubber seed oil from the decorticated seed material using a 50 ton hydraulic press (Moore - Birmingham, UK) the oil was not found to contain cyanide (sensitivity of test $3 \mathrm{mgkg}^{-1}$ ). However the meal contained total cyanide. On moistening the meal $1: 1$ with water, cyanide levels fell markedly (Table 7) showing that despite an expelling temperature of $80^{\circ} \mathrm{C}$, linamarase was still active. (Table 8) follows the fate of total cyanide (cyanogenic glucoside plus $\mathrm{HCN}$ ) content of a single batch of seeds on processing.

Table 7: Detoxification of Rubber Seed Meal

\begin{tabular}{cc}
\hline Time of Soaking & $\begin{array}{c}\text { Total Cyanide } \\
\text { (mgkg }\end{array}$ \\
\hline 0 & 198 \\
1 & 13 \\
6 & 10 \\
24 & 10 \\
\hline & Temperature of expelling oil from kernel, $800 \mathrm{C}:$ \\
& Total cyanide determined by autolysis $(24 \mathrm{~h})$.
\end{tabular}

Treatment of the meal with exogenous linamarase ${ }^{4}$ did not produce an additional quantum of $\mathrm{CN}^{-}$showing that detoxification below the limits set for animal foed has been achieved. This finding is particularly valuable as rubber seed meal has high protein $(30 \%)$ and carbohydrate $(40 \%)$ content. The latter is nearly fully digestible. ${ }^{2}$ As a result seed meal can be used as a component in animal feed. 
Table 8: Variation of Cyamogenic Glucoside Content with Processing

\begin{tabular}{llc}
\hline & Stage of processing & $\begin{array}{c}\text { Total Cyanide } \\
\left(\mathrm{mgkg}^{-1} \text { on dry basis }\right)\end{array}$ \\
\hline 1. & Rubber seed kernel & 1839 \\
2. & $\begin{array}{l}\text { After drying in kiln at } 75^{\circ} \mathrm{C} \\
\text { for } 8 \mathrm{~h} \text { (and storage) }\end{array}$ & 236 \\
3. Meal (after expelling at & \\
& $\left.70-80^{\circ} \mathrm{C}\right)$ & 124 \\
4. After detoxification & (Mcal soaked with 1:1 water)
\end{tabular}

The same batch of seeds

\section{Acknowledgernents}

The authors thank the Natural Resources Energy and Science Authority (NARESA) for a grant (No. RG/88/C/04), the Ceylon Institute of Scientific and Industrial Kescarch for facilities provided and Ms Devika Tennekoon for secretarial assistance.

This paper forms a part of the M.Phil thesis (University of Sri fayewardenepura, Sri Lanka) of Ms G.V. Mallika.

\section{References}

1. AMERICAN OL CHEMISTS SOCIETY, (1970) Sampling and analysis of commercial fats and oils, Ca $5 \mathrm{~A}-40$.

2. MALLIKA, G.V., M. Phil thesis (1991) Applied chemical studies on rubber seed to support its industrial utilization. University of Sri Jayewardenepura, Sri Lanka.

3. MALLIKA, G.V., PIERIS, N.M., JANSZ, E.R. \& ABEYSEKARA, AM. (1991) Problems associated with the estimation of total cyanide in rubber seed kernel. Submitted to J. Nat., Sci., Coun. Sri Lanka.

4. PIERIS, N.M., JANSZ, E.R. \& KANDAGE, R.L. (1974) J. Nati. Sci. Coun. Sri Lanka 2: 67.

5. SAMARANAYAKE, C. (1984) Nursery establishment and management. Rubber Research Insitute of Sri Lanka, Bulletin, 19: 27.

6. TODT, K.H. \& VOGT, K.F.T. (1985) Development of a rubber seed processing technology for the production of vegetable oil and animal feed. Phase $I$ report for UNIDO US/GLO/81/103 by NATEC, FRG. (CONFIDENTIAL REPORT)

7. UNIDO Report on Rubber seed processing for the production of vegetable oil and animal feed. 1989 US/GLO/81/103 prepared by CISIR, Sri Lanka, 1989. (CONFIDENTIAL REPORT) 